\title{
RESPON TERHADAP PENGGUNAAN STYLUS PEN DAN FITUR RECORD DALAM PEMBELAJARAN MATEMATIKA ONLINE
}

\section{(RESPONSE OF USING STYLUS PEN AND RECORDING FEATURE IN ONLINE MATHEMATICS LEARNING)}

\author{
Suci Wulandari ${ }^{1}$, Widdya Rahmalina ${ }^{2}$, Sri Novia Martin ${ }^{3}$, Lisa Yuniarti ${ }^{4}$ \\ ${ }^{1}$ STKIP Adzkia, suci.w@stkipadzkia.ac.id \\ ${ }^{2}$ STKIP Adzkia, widdyarahmalina@stkipadzkia.ac.id \\ ${ }^{3}$ STKIP Adzkia, noviamart@stkipadzkia.ac.id \\ ${ }^{4}$ STKIP Adzkia, lisa.y@ stkipadzkia.ac.id
}

\begin{abstract}
Abstrak
Pandemi Covid-19 berdampak negatif terhadap pembelajaran yang dilaksanakan secara online. Yang menjadi masalah adalah sulitnya memahami konsep-konsep pada materi pembelajaran matematika. Pendidik diharuskan untuk kreatif dalam memanfaatkan produk teknologi. Salah satunya pemanfaatan stylus pen dan fitur record yang tersedia dalam aplikasi meeting online seperti Google Meet. Tujuan penelitian ini adalah untuk mengetahui persepsi mahasiswa terhadap perkuliahan matematika daring dengan menggunakan stylus pen dan fitur record tersebut. Penelitian ini menggunakan metode survei dengan subjek penelitian yaitu 104 mahasiswa STKIP Adzkia yang terlibat dalam pembelajaran matematika online dengan menggunakan stylus pen dan memanfaatkan fitur record yang tersedia pada aplikasi Google Meet. Hasil dari penelitian ini menunjukkan bahwa teknik penggunaan stylus pen dan fitur record ketika pembelajaran matematika online ini dapat berdampak pada pemahaman konsep matematika yang lebih baik, komunikasi matematis, suasana pembelajaran, hasil belajar, dan keefektifan pembelajaran matematika online.
\end{abstract}

Kata Kunci: Teknik Pembelajaran Matematika; Stylus Pen; Pembelajaran Online

\begin{abstract}
The Covid-19 pandemic has a negative impact on learning carried out online. The problem is the difficulty in understanding the concepts in mathematics learning material. Educators are required to be creative in utilizing technology products. One of them is the use of the stylus pen and the recording feature available in online meeting application such as Google Meet. The purpose of this study was to determine students' perceptions of online mathematics lectures using a stylus pen and the recording feature. This study used a survey method with the research subjects of 104 STKIP Adzkia students who are involved in learning mathematics online using a stylus pen and take advantage of the recording feature available on the application, Google Meet. The results of this study indicate that the technique of using a stylus pen and the recording feature when learning mathematics online can have an impact on better understanding of mathematical concepts, mathematical communication, learning atmosphere, learning outcomes, and the effectiveness of online mathematics learning.
\end{abstract}


Keywords: Mathematics learning techniques; Stylus Pen; Online learning

\section{PENDAHULUAN}

Pandemi Covid-19 sangat banyak memberikan dampak terhadap aspekaspek kehidupan. Salah satu aspek yang terdampak yaitu aspek pendidikan. Dampak positif yang dirasakan diantaranya yaitu membuat guru atau pendidik jadi lebih mengenal dan melek teknologi (Arrafi, 2020). Namun yang menjadi masalah yaitu dampak negatifnya terhadap pembelajaran yang dilaksanakan secara online atau lebih dikenal dengan istilah pembelajaran daring (dalam jaringan). Dampak negatif tersebut terkait dengan sulitnya mahasiswa memahami materi belajar yang diberikan secara online dalam pembelajaran daring (Muhassanah, Winarni and Hayati, 2020). Kondisi seperti ini mengharuskan semua pihak terkait terutama guru untuk meningkatkan kapasitas dirinya supaya dapat beradaptasi dengan pembelajaran jarak jauh dengan cara menguasai teknologi dan produk teknologi yang dapat menciptakan pembelajaran secara daring (Febrian, Astuti and Antika, 2020; Rahmi, 2020).

Sebagai ilmu pengetahuan yang abstrak, konsep matematika yang dianggap sulit menjadi semakin sulit untuk dipahami jika pembelajaran matematika dilaksanakan secara daring. Oleh karena itu diperlukan adanya kreatifitas dan teknik khusus dalam pembelajaran matematika daring. Para pendidik dapat menggunakan aplikasi pembelajaran dan mencari cara yang tepat untuk meningkatkan motivasi mahasiswa dalam pembelajaran daring sehingga diharapkan juga dapat meningkatkan pemahaman terhadap materi yang diajarkan (Kusumaningrum and Wijayanto, 2020). Inilah tantangan bagi pendidik agar materi matematika yang diajarkan melalui platform pembelajaran online tetap dipahami oleh peserta didik sehingga tercapai tujuan pembelajaran matematika itu sendiri (Febrian, Astuti and Antika, 2020).

Penjelasan materi ataupun pemberian tugas mandiri tanpa didukung oleh teknik yang tepat saat menjelaskan konsep belum tentu menjadi solusi dari permasalahan dalam pembelajaran matematika secara daring. Salah satu teknik pembelajaran yang dapat digunakan yaitu penggunaan stylus pen dan pemanfaatan fitur perekaman (record) yang tersedia dalam aplikasi meeting online seperti Zoom Meeting, Google Meet dan lain-lain untuk pembelajaran matematika daring. Dengan menggunakan stylus pen dan dikolaborasikan dengan perekaman kegiatan pembelajaran akan dapat menjadi solusi dari permasalahan pembelajaran matematika online.

Tujuan penelitian ini adalah untuk mengetahui persepsi mahasiswa terhadap perkuliahan matematika daring dengan menggunakan stylus pen dan fitur record. Dengan mengetahui persepsi ini, dapat menjadi rekomendasi bagi pendidik yang mengalami kendala dalam pembelajaran matematika secara daring.

\section{KAJIAN TEORI}

\section{Teknik Pembelajaran Matematika Online}

Karakteristik matematika yaitu sebagai ilmu yang memilki objek kajian yang abstrak. Untuk memahami konsep matematika diperlukan arahan atau bimbingan dari seorang pendidik agar peserta didik dapat mengkonstruk pengetahuan. Dalam rangka penyampaian konsep-konsep dasar matematika 
dibutuhkan teknik tertentu supaya tidak terjadi kesalahpahamam atau miskonsepsi yang berakibat pada kesalahan dalam penyelesaian masalah matematika. Seperti yang diungkapkan oleh Kamarullah bahwa tujuan pembelajaran matematika diantaranya memahami konsep matematika, menggunakan penalaran dalam memanipulasi matematika dalam membuat generalisasi, meyusun bukti, merancang model matematika hingga mampu menyelesaikan masalah matematika (Kamarullah, 2017).

Untuk dapat mencapai tujuan pembelajaran matematika diperlukan teknik tertentu. Teknik pembelajaran adalah cara menyajikan materi yang lebih khusus sesuai dengan kekhususan bidang studi (D. A. Muiz Lidinillah, 2006). Oleh karena itu perlu adanya alat, media dan perangkat dalam upaya mencapai tujuan pembelajaran khususnya pembelajaran matematika secara daring.

Begitulah kondisinya sekarang ini dimana pembelajaran tatap muka di perguruan tinggi yang sudah berlangsung sejak lama beralih menjadi pembelajaran yang dilakukan dalam jaringan (daring). Transisi dari pembelajaran tatap muka menjadi pembelajaran daring merupakan dampak dari penyebaran virus Covid-19 di Indonesia (Ghifari, 2020). Pilihan institusi perguruan tinggi untuk tetap menyelenggarakan perkuliahan di masa pandemi Covid-19 adalah dengan melakukan pembelajaran online (Anggrawan, 2019). Bentley, Selassie, dan Shegunshi menyebutkan bahwa pembelajaran online yaitu sistem pembelajaran yang mengintegrasikan koneksi internet dengan proses belajar mengajar (Muhassanah, Winarni and Hayati, 2020). Pembelajaran online adalah pembelajaran yang dilaksanakan tanpa adanya pertemuan secara langsung tetapi memanfaatkan platform khusus untuk bertatap muka (Lubis, 2021). Pelaksanaan pembelajaran secara online tidak mengharuskan peserta didik untuk masuk ke ruangan kelas untuk belajar seperti biasanya. Pendidik dan peserta didik hanya perlu memiliki fasilitas yang mendukung untuk mengakses internet agar dapat mengikuti kegiatan pembelajaran. Perangkat yang dibutuhkan diantaranya seperti laptop, komputer atau smartphone yang mampu menjalankan aplikasi seperti Zoom Meeting, Google Meet, dan sejenisnya (Lubis, 2021).

\section{Stylus Pen}

Definisi stylus adalah berbagai jenis instrumen runcing berbentuk pena yang digunakan untuk menulis atau menggambar (DICTIONARY.COM, 2021). Dalam Wikipedia disebutkan bahwa stylus pen atau pena digital adalah sebuah alat berbentuk pena kecil yang dipakai untuk mengusap layar komputer, peranti bergerak atau tablet grafis. stylus pen merupakan sebuah alat yang digunakan untuk memudahkan seseorang dalam menulis pada layar. Biasanya stylus pen banyak digunakan oleh para designer grafis dan pekerja yang suka mencatat di smartphone. 


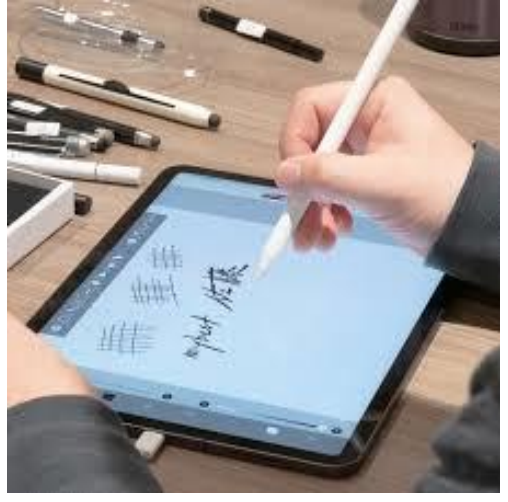

Sumber:

https://www.google.com/url? sa=i\&url=htt ps\%3A\%2F\%2Fmy-

best.id\%2F9330\&psig=AOvVaw1aRVI_L4 jCZnAO-

$\underline{3 G s Z w u T \& \text { ust }=1614837589998000 \& \text { sourc }}$ e=images \&cd $=v f e \& v e d=2 a h U K E w i B w N L$ 4uJPvAhXXkksFHZ5QAqoQr4kDegUIARD $\underline{A Q}$

Gambar 1. Stylus pen

Dengan adanya stylus pen, pendidik yang melaksanakan pembelajaran online dapat membagikan layarnya sembari menulis seperti sedang menggunakan papan tulis saat pembelajaran di kelas secara tatap muka langsung. Ada banyak model stylus pen yang bisa digunakan, mulai dari yang harganya murah sampai yang membutuhkan biaya yang cukup besar. Namun, stylus pen yang digunakan peneliti pada penelitian ini seperti gambar 2 di bawah ini.

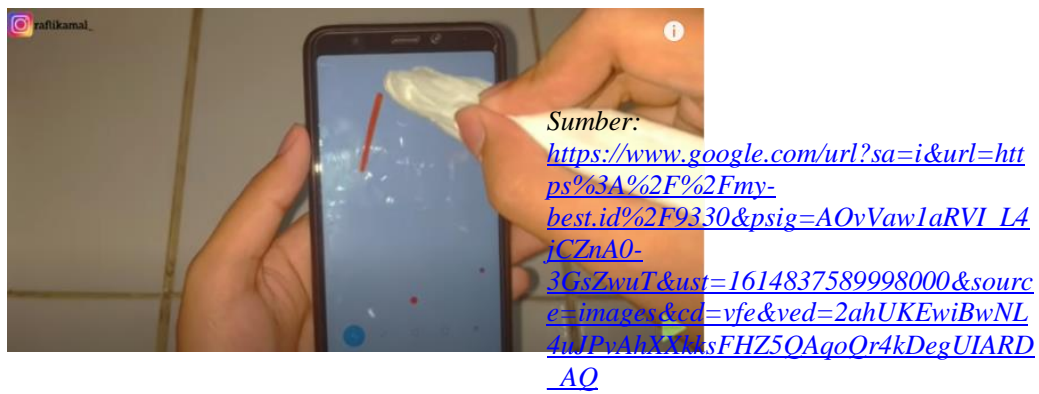

Gambar 2. Stylus pen Buatan

\section{Fitur Record dalam Aplikasi Meeting Online}

Media pembelajaran yang bisa digunakan peserta didik untuk belajar di rumah salah satunya yaitu video pembelajaran. Video pembelajaran adalah salah satu contoh dari media audio-visual yang terdapat urutan gambar diam, suara dan berisi materi yang akan disampaikan saat pembelajaran (Purbayanti, Ponoharjo and Oktaviani, 2020). Untuk memfasilitasi mahasiswa dalam perkuliahan daring dalam penelitian ini, peneliti menggunakan fitur rekaman pada Google Meet. Google memberikan layanan untuk merekam pembelajaran online yang dilaksanakan pada Google Meet. Rekaman akan menyertakan pembicara aktif dan apa pun yang dipresentasikan (Google, 2021). Hasil rekaman disimpan dalam Google Drive penyelenggara meeting (perkuliahan) yaitu guru atau dosen. Dengan demikian mahasiwa bisa mengulang pelaksanaan perkuliahan yang telah berlangsung dengan mengakses link video pada google drive yang dibagikan oleh penyelenggara meeting (perkuliahan).

\section{METODE}

Penelitian ini dilaksanakan dengan metode penelitian survei. Menurut Suwartono, penelitian survei adalah penelitian yang melibatkan subjek yang 
banyak, sebagian dari semua subjek, atau bisa juga seluruh populasi (sering disebut dengan sensus) (Islamy, 2019). Pada penelitian ini, subjek penelitian berjumlah 104 mahasiswa yang berasal dari lima kelas mata kuliah antara lain 1 kelas mata kuliah Kalkulus, 1 kelas mata kuliah Kalkulus Vektor, 1 kelas mata kuliah Statistik Pendidikan, dan 2 kelas mata kuliah Dasar-Dasar Matematika Sekolah Dasar. Kelima mata kuliah tersebut dilaksanakan secara online menggunakan aplikasi Google Meet. Selama pelaksanaan perkuliahan peneliti menggunakan stylus pen dan memanfaatkan fitur record. Penelitian ini dilakukan di STKIP Adzkia.

Pengumpulan data pada penelitian ini dilaksanakan menggunakan kuisioner atau angket yang disebar secara online menggunakan Google Form setelah perkuliahan selesai dilaksanakan yaitu pada bulan Februari 2021. Berdasarkan tujuan dari survei pada penelitian ini yaitu untuk memberikan gambaran tentang respon mahasiswa terhadap perkuliahan yang dilaksanakan secara online tersebut, maka survei pada penelitian ini tergolong survei deskriptif. Survei deskriptif berkaitan dengan situasi yang memerlukan teknik pengumpulan data tertentu seperti wawancara, angket, atau observasi (Islamy, 2019). Dilihat dari proses pelaksanaan dan perlakuannya terhadap subjek penelitian, maka survei ini dikategorikan pada Survei Sekali Waktu (Cross-sectional Survei. Menurut Yusuf (Islamy, 2019), penelitian survei jenis Survei Sekali Waktu (Crosssectional Survei) artinya data hanya diperoleh/dikumpulkan untuk waktu tertentu saja dengan tujuan menggambarkan kondisi populasi yang ada.

Kuisioner survey yang disebar terdiri atas 10 butir pernyataan yang dapat diisi oleh para responden atau subjek penelitian. Peneliti menyebarkan kuisioner dibuat menggunakan skala Likert. Menurut Bahrun, Alifah, \& Mulyono; Saputra \& Nugroho (Pranatawijaya et al., 2019), skala Likert adalah skala yang digunakan untuk mengukur persepsi, sikap atau pendapat seseorang atau kelompok mengenai sebuah peristiwa atau fenomena sosial.

Data yang diperoleh dari kuisioner pada penelitian ini dianalisis dengan teknik persentase terhadap jawaban yang diberikan oleh subjek atau responden untuk sepuluh item pernyataan yang ada pada kuisionier. Untuk menerjemahkan hasil skala likert tersebut peneliti menggunakan analisis interval. Jawaban dari responden diberi bobot atau skor. Bobot atau skor yang diberikan untuk suatu pernyataan dengan respon Sangat Tidak Setuju $(\mathrm{STS})=1$, Tidak Setuju $(\mathrm{TS})=2$, Kurang Setuju $(K S)=3$, Setuju $(S)=4$, dan Sangat Setuju $(S S)=5$. Persentase indeks penilaian untuk setiap pernyataan dapat dihitung dengan rumus sebagai berikut.

$$
\operatorname{Indeks}(\%)=\frac{\text { Skor total respon }}{\text { Skor maksimumrespon }} \times 100 \%
$$

Hasil perhitungan indeks penilaian setiap pernyataan dapat disimpulkan berdasarkan interval (Pranatawijaya et al., 2019) berikut ini:

\begin{tabular}{ll}
\multicolumn{2}{c}{ Tabel 1. Interval Penilaian Skala Likert } \\
\hline Indeks Penilaian & \multicolumn{1}{c}{ Kesimpulan } \\
\hline $0 \%-19,99 \%$ & Sangat Tidak Setuju (STS) \\
$20 \%-39,99 \%$ & Tidak Setuju (TS)
\end{tabular}




\begin{tabular}{ll}
\hline $40 \%-59,99 \%$ & Kurang Setuju (KS) \\
$60 \%-79,99 \%$ & Setuju (S) \\
$80 \%-100 \%$ & Sangat Setuju (SS)
\end{tabular}

Dengan demikian dapat diambil kesimpulan terhadap setiap butir pernyataan pada kuisioner terkait dengan penggunaan stylus pen dan fitur record pada pembelajaran matematika online.

\section{HASIL DAN PEMBAHASAN}

Penelitian survei ini dilakukan dengan menyebar angket secara online melalui link Google Form kepada 124 mahasiswa sebagai berikut.

Tabel 2. Responden Penelitian

\begin{tabular}{clcc}
\hline No. & \multicolumn{1}{c}{ Mata Kuliah } & Jumlah Mahasiswa & $\begin{array}{c}\text { Jumlah Mahasiswa } \\
\text { yang merespon }\end{array}$ \\
\hline 1. & Kalkulus & 16 orang \\
2. & Kalkulus Vektor & 9 orang & 104 \\
3. & Statistik Pendidikan & 15 orang & responden \\
4. & Dasar-Dasar Matematika SD kelas A & 42 orang & \\
5. & Dasar-Dasar Matematika SD kelas E & 42 orang \\
\hline & \multicolumn{3}{c}{ Total } \\
\hline
\end{tabular}

Berdasarkan tabel di atas, dari 124 mahasiswa yang diberikan kuisioner, ada 104 mahasiswa yang memberikan respon. Dengan demikian ada 83,87\% mahasiswa yang menjadi subjek atau responden pada penelitian ini, dan 16,13\% mahasiswa tidak mengisi kuisioner yang diberikan. Berikut disajikan respon setiap butir pernyataan pada kuisioner.

Tabel 3. Respon Setiap Butir Penyataan Kuisioner

\begin{tabular}{cccccccc}
\hline $\begin{array}{c}\text { Nomor } \\
\text { Pernyataan }\end{array}$ & STS (1) & TS (2) & KS (3) & S (4) & SS (5) & Penilaian & Kesimpulan \\
\hline 1. & 1 & 1 & 14 & 44 & 44 & $88,2 \%$ & $\begin{array}{c}\text { Sangat } \\
\text { Setuju }\end{array}$ \\
& $(1 \%)$ & $(1 \%)$ & $(13,5 \%)$ & $(42,3 \%)$ & $(42,3 \%)$ & & \\
2. & 3 & 3 & 11 & 46 & 41 & $86,2 \%$ & $\begin{array}{c}\text { Sangat } \\
\text { Setuju }\end{array}$ \\
& $(2,9 \%)$ & $(2,9 \%)$ & $(10,6 \%)$ & $(44,2 \%)$ & $(39,4 \%)$ & & \\
3. & 2 & 5 & 19 & 39 & 39 & $84 \%$ & $\begin{array}{c}\text { Sangat } \\
\text { Setuju }\end{array}$ \\
\hline
\end{tabular}




$(1,9 \%) \quad(4,8 \%) \quad(18,3 \%) \quad(37,5 \%) \quad(37,5 \%)$

\begin{tabular}{|c|c|c|c|c|c|}
\hline $\begin{array}{c}0 \\
(0 \%)\end{array}$ & $\begin{array}{c}2 \\
(1,9 \%)\end{array}$ & $\begin{array}{c}18 \\
(17,3 \%)\end{array}$ & $\begin{array}{c}40 \\
(38,5 \%)\end{array}$ & $\begin{array}{c}44 \\
(42,3 \%)\end{array}$ & $87,6 \%$ \\
\hline
\end{tabular}

5

\begin{tabular}{|c|c|c|c|}
\hline 0 & 5 & 6 & 49 \\
\hline$(0 \%)$ & $(4,8 \%)$ & $(5,8 \%)$ & $(47,1 \%)$ \\
\hline
\end{tabular}

\begin{tabular}{|c|c|c|c|}
\hline 0 & 5 & 6 & 49 \\
\hline$(0 \%)$ & $(4,8 \%)$ & $(5,8 \%)$ & $(47,1 \%)$ \\
\hline
\end{tabular}

Sangat

6. $\begin{array}{cccccrr} & & & & \text { Sangat } \\ \text { Setuju }\end{array}$

\begin{tabular}{|c|c|c|c|c|c|c|c|}
\hline 7. & $\begin{array}{c}0 \\
(0 \%)\end{array}$ & $\begin{array}{c}7 \\
(6,7 \%)\end{array}$ & $\begin{array}{c}9 \\
(8,7 \%)\end{array}$ & $\begin{array}{c}42 \\
(40,4 \%)\end{array}$ & $\begin{array}{c}46 \\
(44,2 \%)\end{array}$ & $87,8 \%$ & $\begin{array}{l}\text { Sanga } \\
\text { Setuju }\end{array}$ \\
\hline 8. & $\begin{array}{c}0 \\
(0 \%)\end{array}$ & $\begin{array}{c}6 \\
(5,8 \%)\end{array}$ & $\begin{array}{c}4 \\
(3,8 \%)\end{array}$ & $\begin{array}{c}29 \\
(27,9 \%)\end{array}$ & $\begin{array}{c}65 \\
(62,5 \%)\end{array}$ & $93 \%$ & $\begin{array}{l}\text { Sanga } \\
\text { Setuju }\end{array}$ \\
\hline 9. & $\begin{array}{c}1 \\
(1 \%)\end{array}$ & $\begin{array}{c}4 \\
(3,8 \%)\end{array}$ & $\begin{array}{c}9 \\
(8,7 \%)\end{array}$ & $\begin{array}{c}36 \\
(34,6 \%)\end{array}$ & $\begin{array}{c}54 \\
(51,9 \%)\end{array}$ & $90 \%$ & $\begin{array}{l}\text { Sanga } \\
\text { Setuju }\end{array}$ \\
\hline 10. & $\begin{array}{c}0 \\
(0 \%)\end{array}$ & $\begin{array}{c}2 \\
(1,9 \%)\end{array}$ & $\begin{array}{c}17 \\
(16,3 \%)\end{array}$ & $\begin{array}{c}38 \\
(36,5 \%)\end{array}$ & $\begin{array}{c}47 \\
(45,2 \%)\end{array}$ & $88,4 \%$ & $\begin{array}{l}\text { Sanga } \\
\text { Setuju }\end{array}$ \\
\hline
\end{tabular}

Keterangan:

1. Pemahaman terhadap materi/konsep matematika yang dijelaskan menggunakan stylus pen lebih baik dibandingkan dengan penjelasan tanpa stylus pen.

2. Penggunaan stylus pen ketika pembelajaran matematika daring mengatasi masalah keterbatasan komunikasi matematis.

3. Penggunaan stylus pen dalam pembelajaran matematika daring mengatasi kesulitan dalam memahami konsep matematika.

4. Penggunaan stylus pen dalam pembelajaran matematika daring dapat menghadirkan suasana belajar ketika pengajar menjelaskan di papan tulis dalam ruangan kelas biasanya.

5. Hasil dari pembelajaran matematika dengan teknik penggunaan stylus pen lebih efektif dibandingkan tanpa stylus pen.

6. Video rekaman selama pembelajaran dapat membantu dalam memaksimalkan pemahaman terhadap materi/konsep matematika yang dibahas.

7. Teknik penggunaan stylus pen akan semakin berdampak positif terhadap pemahaman jika dikolaborasikan dengan perekaman selama pembelajaran daring berlangsung.

8. Video rekaman dapat mengatasi kendala jaringan yang tidak stabil selama 
pembelajaran daring.

9. Hasil rekaman berbentuk link lebih disukai karena tidak menghabiskan memori penyimpanan pada perangkat yang digunakan.

10. Hasil rekaman lebih baik dapat didownload dan disimpan supaya tidak menghabiskan kuota internet selama menonton ulang video.

Pernyataan 1 sampai dengan 5 pada kuisioner bertujuan untuk mengetahui respon mahasiswa terhadap penggunaan stylus pen ketika dosen memberikan penjelasan materi/konsep matematika dalam pembelajaran online. Pernyataan 1 berbunyi "Pemahaman terhadap materi/konsep matematika yang dijelaskan menggunakan stylus pen lebih baik dibandingkan dengan penjelasan tanpa stylus pen". Persentase terbesar dari responden memilih setuju dengan pernyataan ini. Hal ini dapat dilihat pada gambar 1. Sedangkan hasil perhitungan indeks penilaian untuk pernyataan ini menunjukkan indeks sebesar 88,2\% (tabel 3). Berdasarkan bilangan ini dapat disimpulkan bahwa perkuliahan online yang menggunakan stylus pen dalam memberikan penjelasan materi/konsep matematika berdampak pada pemahaman yang lebih baik dari pada tidak menggunakan stylus pen. Hal yang sama diungkapkan oleh Isharyadi dan Annajmi bahwa penggunaan stylus pen atau pen tablet dalam pembelajaran online bisa menjadi metode yang sangat baik untuk berkomunikasi secara visual dengan mahasiswa dan meningkatkan pemahaman dan retensi mereka (Isharyadi and Annajmi, 2019).

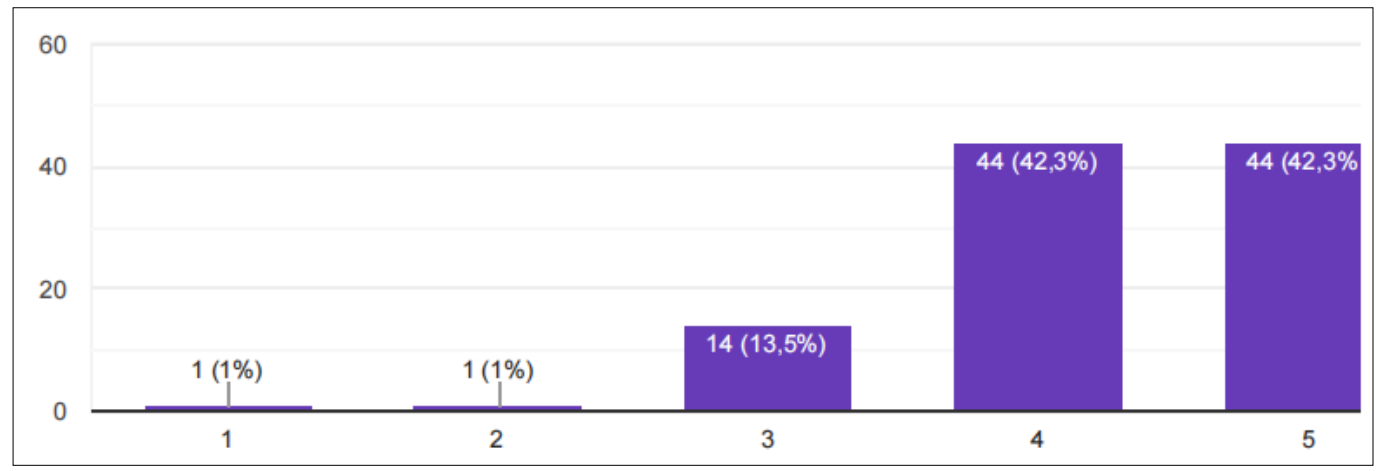

Gambar 1. Respon untuk Pernyataan 1

Pernyataan 2 berbunyi "Penggunaan stylus pen ketika pembelajaran matematika daring mengatasi masalah keterbatasan komunikasi matematis". Persentase terbesar dari responden memilih setuju dengan pernyataan ini. Hal ini dapat dilihat pada gambar 2. Sedangkan hasil perhitungan indeks penilaian untuk pernyataan ini menunjukkan indeks sebesar 86,2\% (Tabel 3). Berdasarkan bilangan ini dapat disimpulkan bahwa perkuliahan online yang menggunakan stylus pen dapat mengatasi keterbatasan komunikasi matematis. Dalam pembelajaran matematika, pengomunikasian objek matematika membutuhkan kemampuan khusus. Hal ini dikarenakan bahwa pesan yang disampaikan dalam mempelajari matematika berisi tentang materi matematika yang berupa konsep, rumus, atau strategi penyelesaian suatu masalah (Nofrianto, Maryuni and Amri, 2017). Oleh karena itu diperlukan kemampuan komunikasi matematis yang baik dalam menjelaskan materi matematika. Dengan berbantuan stylus pen, penyampaian pesan berupa objek matematika dapat lebih mudah dipahami. 


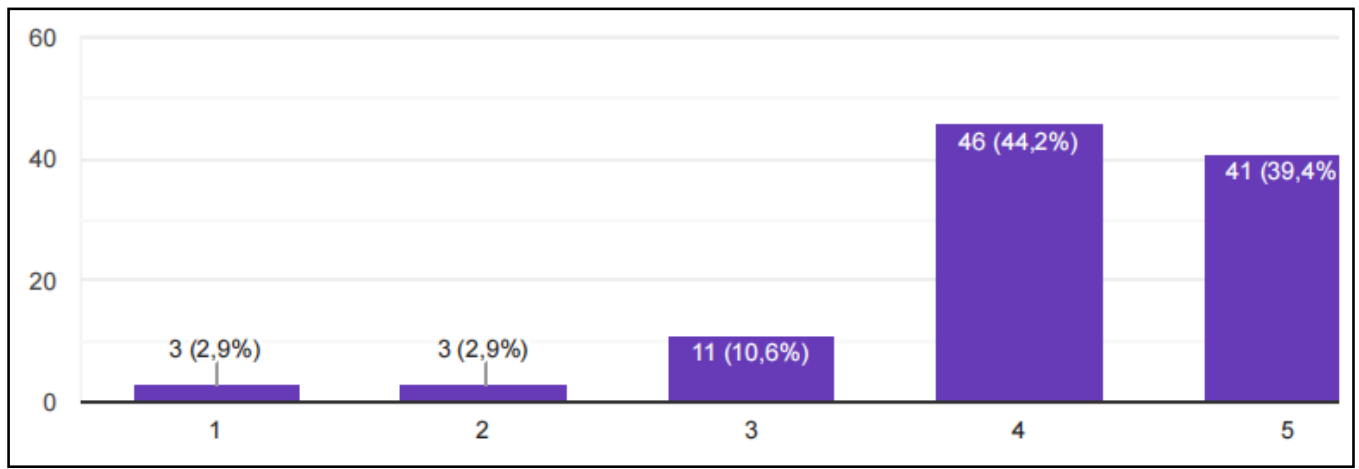

Gambar 2. Respon untuk Pernyataan 2

Pernyataan 3 berbunyi "Penggunaan stylus pen dalam pembelajaran matematika daring mengatasi kesulitan dalam memahami konsep matematika". Persentase terbesar dari responden memilih setuju dan sangat setuju dengan pernyataan ini. Hal ini dapat dilihat pada gambar 3. Sedangkan hasil perhitungan indeks penilaian untuk pernyataan ini menunjukkan indeks sebesar $84 \%$ (tabel 3). Berdasarkan bilangan ini dapat disimpulkan bahwa penggunaan stylus pen dapat mengatasi kesulitan dalam memahami konsep matematika selama perkuliahan online. Kesulitan belajar diartikan dengan kesukaran siswa dalam menerima atau menyerap pelajaran (Silalahi et al., 2020). Jika dikaitkan dengan kesulitan dalam pembelajaran matematika, kesulitan dalam memahami materi ketika pembelajaran online dapat diberikan rekomedasi untuk memberikan penjelasan dengan menggunakan stylus pen.

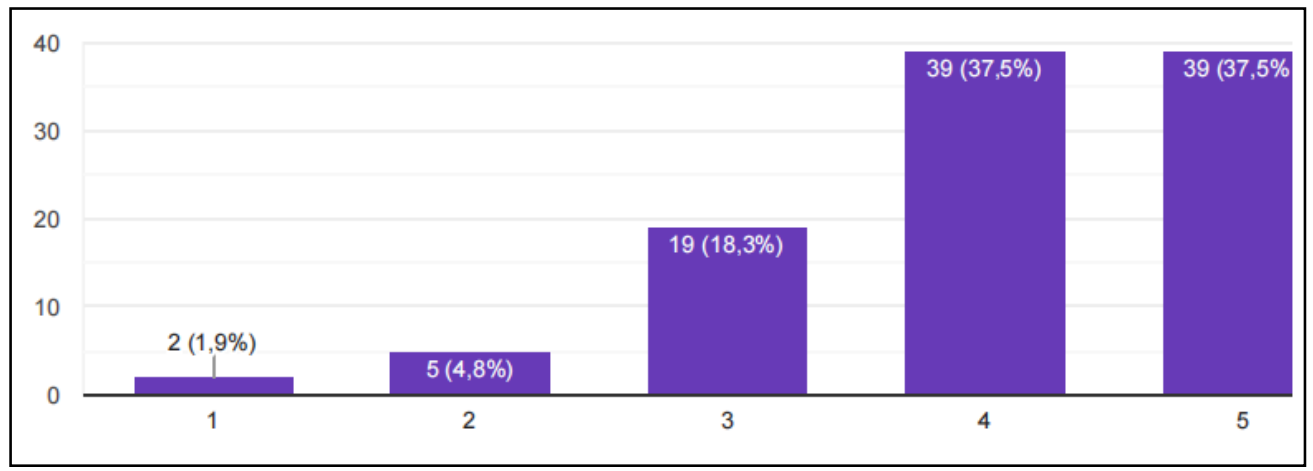

Gambar 3. Respon untuk Pernyataan 3

Pernyataan 4 berbunyi "Penggunaan stylus pen dalam pembelajaran matematika daring dapat menghadirkan suasana belajar ketika pengajar menjelaskan di papan tulis dalam ruangan kelas biasanya". Persentase terbesar dari responden memilih sangat setuju dengan pernyataan ini. Hal ini dapat dilihat pada gambar 4. Sedangkan hasil perhitungan indeks penilaian untuk pernyataan ini menunjukkan indeks sebesar 87,6\% (tabel 3). Berdasarkan bilangan ini dapat disimpulkan bahwa penggunaan stylus pen ketika pembelajaran matematika online dapat menghadirkan suasana belajar ketika pengajar menjelaskan di papan tulis dalam ruangan kelas biasanya. Suasana belajar matematika di kelas dapat dihadirkan meskipun pelaksanaannya secara jarak jauh atau dalam jaringan internet. Pen tablet dapat dimanfaatkan untuk menulis di layar laptop layaknya menulis di kertas (Ario and Isharyadi, 2020). Dengan adanya stylus pen atau pen tablet ini akan merasa melihat tulisan dosen saat memberikan penjelasan di papan 
tulis.

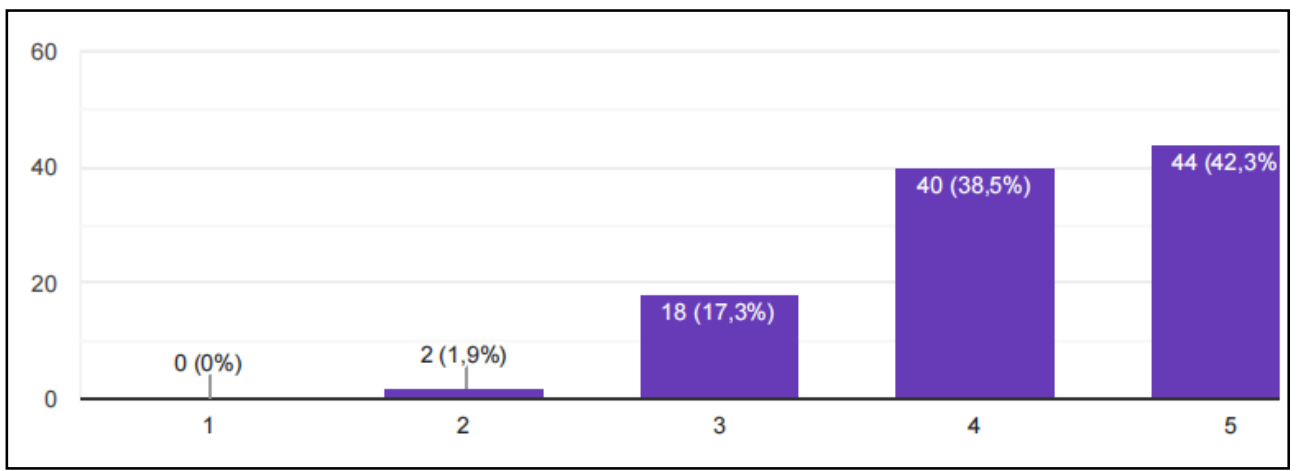

Gambar 4. Respon untuk Pernyataan 4

Pernyataan 5 berbunyi "Hasil dari pembelajaran matematika dengan teknik penggunaan stylus pen lebih efektif dibandingkan tanpa stylus pen”. Persentase terbesar dari responden memilih setuju dengan pernyataan ini. Hal ini dapat dilihat pada gambar 5. Sedangkan hasil perhitungan indeks penilaian untuk pernyataan ini menunjukkan indeks sebesar $88,8 \%$ (tabel 3). Berdasarkan bilangan ini dapat disimpulkan bahwa dengan penggunaan stylus pen, pembelajaran matematika online lebih efektif dari pada tidak menggunakan stylus pen. Sebuah penelitian yang menerapkan video pembelajaran dengan memaksimakan penggunaan aplikasi atau software pembelajaran seperti Cam Studio dan Pen Tablet menunjukkan hasil bahwa terdapat perbedaan yang signifikan dengan pembelajaran biasa (Koswara and Tita Rosita, 2020). Selain itu, manfaat dan karakteristik lain dari video pembelajaran adalah dalam meningkatkan efektifitas dan efisiensi proses pembelajaran.

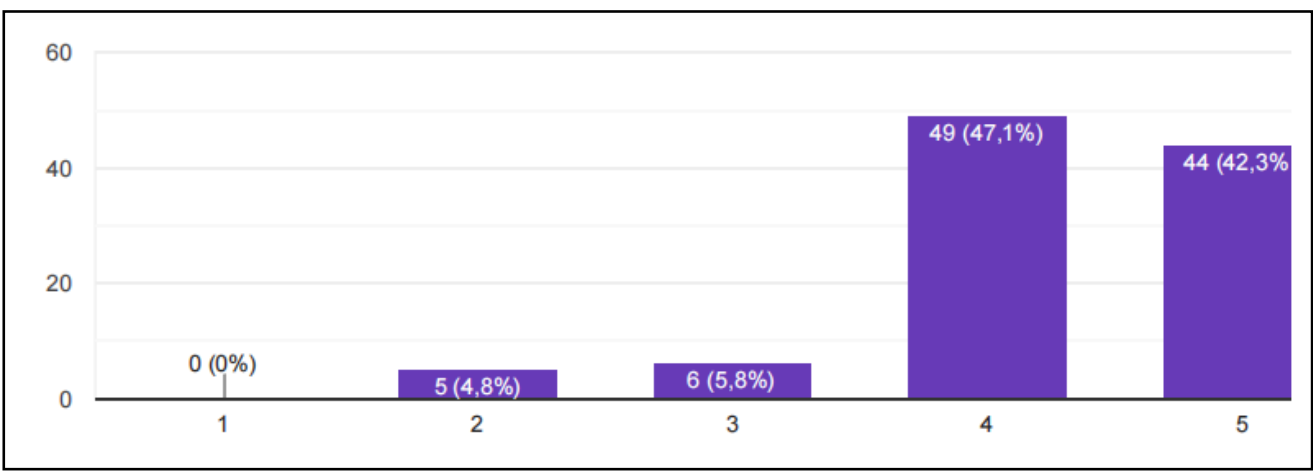

Gambar 5. Respon untuk Pernyataan 5

Pernyataan 6, 8, 9, dan 10 pada kuisioner bertujuan untuk mengetahui respon mahasiswa terhadap pemanfaatan fitur record atau rekam layar selama pembelajaran online. Pernyataan 6 berbunyi "Video rekaman selama pembelajaran dapat membantu dalam memaksimalkan pemahaman terhadap materi/konsep matematika yang dibahas". Persentase terbesar dari responden memilih sangat setuju dengan pernyataan ini. Hal ini dapat dilihat pada gambar 6 . Sedangkan hasil perhitungan indeks penilaian untuk pernyataan ini menunjukkan indeks sebesar 91,6\% (Tabel 3). Berdasarkan bilangan ini dapat disimpulkan bahwa dengan adanya rekaman selama pembelajaran online, pemahaman terhadap materi/konsep matematika bisa lebih maksimal. Video tersebut berupa hasil 
rekaman tentang penjelasan apa yang sedang ditulis (Ario and Isharyadi, 2020). Disamping itu, video rekaman tersebut bisa dijadikan sebagai sumber belajar yang dapat meningkatkan pemahaman terhadap penjelasan saat pembelajaran online, bahkan bisa diulang-ulang penayangannya kapanpun sampai mahasiswa merasa puas dan benar-benar memahami materi matematika.

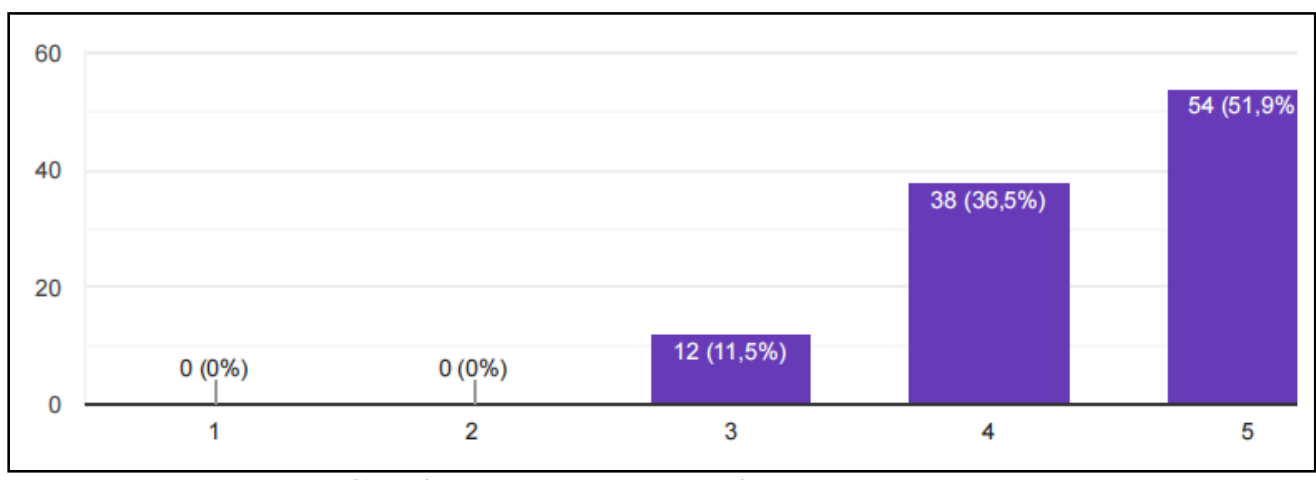

Gambar 6. Respon untuk Pernyataan 6

Pernyataan 8 berbunyi "Video rekaman dapat mengatasi kendala jaringan yang tidak stabil selama pembelajaran daring". Persentase terbesar dari responden memilih sangat setuju dengan pernyataan ini. Hal ini dapat dilihat pada gambar 7 . Sedangkan hasil perhitungan indeks penilaian untuk pernyataan ini menunjukkan indeks sebesar 93\% (Tabel 3). Berdasarkan bilangan ini dapat disimpulkan bahwa dengan adanya rekaman selama pembelajaran online, ketidakstabilan jaringan bukan lagi menjadi kendala yang signifikan. Dengan memanfaatkan aplikasi tambahan screen recording yang tersedia, maka tulisan-tulisan yang dibuat di layar laptop tersebut dapat direkam (Ario and Isharyadi, 2020). Meskipun saat pembelajaran online berlangsung terjadi ketidakstabilan jaringan internet dari mahasiswa, dosen yang menjadi admin dari pembelajaran online tetap dengan jelas dapat merekam layar laptopnya. Sehingga hasil rekaman tersebut dapat diputar saat jaringan sudah membaik.

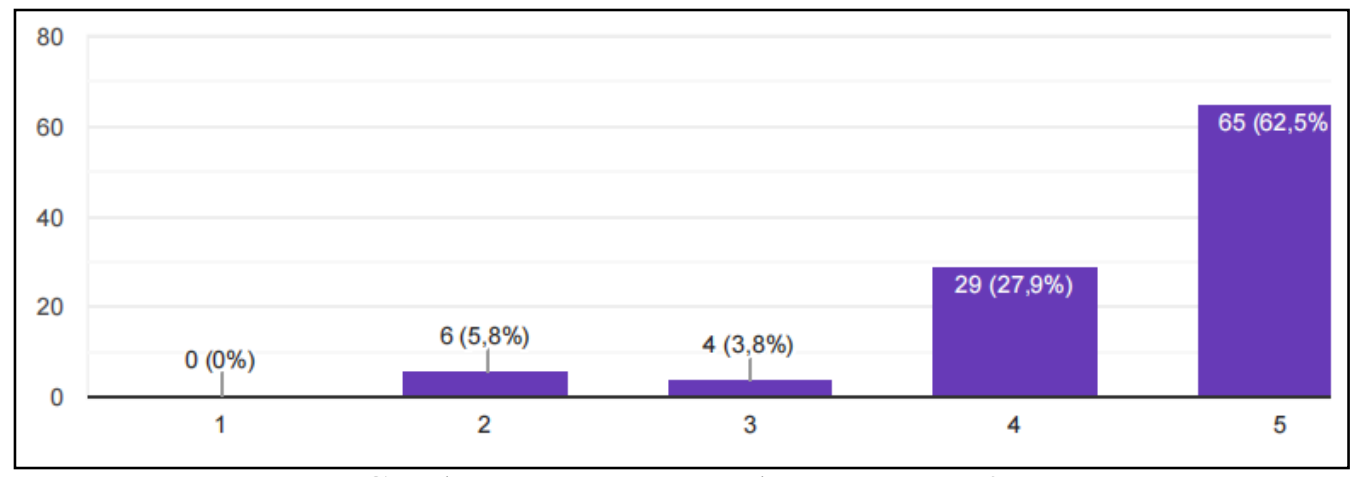

Gambar 7. Respon untuk Pernyataan 8

Pernyataan 9 berbunyi "Hasil rekaman berbentuk link lebih disukai karena tidak menghabiskan memori penyimpanan pada perangkat yang digunakan”. Persentase terbesar dari responden memilih sangat setuju dengan pernyataan ini. Hal ini dapat dilihat pada gambar 8. Sedangkan hasil perhitungan indeks penilaian untuk pernyataan ini menunjukkan indeks sebesar 90\% (tabel 3). Selanjutnya untuk pernyataan 10 yang berbunyi "Hasil rekaman lebih baik dapat didownload 
dan disimpan supaya tidak menghabiskan kuota internet selama menonton ulang video" mendapatkan respon dengan persentase terbesar sangat setuju. Hal ini dapat dilihat pada gambar 9. Sedangkan hasil perhitungan indeks penilaian untuk pernyataan ini menunjukkan indeks sebesar $88,4 \%$ (tabel 3). Kedua respon ini menunjukkan bahwa responden sangat setuju jika video pembelajaran ini dapat diunduh maupun tidak diunduh. Hal ini tergantung pada kondisi perangkat masing-masing pengguna link. Responden yang tidak ingin menghabiskan memori perangkatnya maka ia tidak perlu mengunduh video pembelajaran. Sementara responden yang lebih suka menyimpan video rekaman perkuliahan online, dikarenakan supaya tidak menghabiskan kuota internet saat menonton ulang video tersebut saat offline. Penyimpanan hasil rekaman video pembelajaran bisa berbentuk link yang dibuat dengan menyimpan pada google drive. Bahkan bisa juga menyimpannya dalam perangkat yang digunakan dengan terlebih dahulu mengunduhnya. Dengan demikian, saat memutar ulang video pembelajaran tidak menghabiskan kuota internet. Sehingga saat memutar ulang video mahasiswa bukan hanya membaca apa yang tertulis, tapi juga dapat mendengarkan penjelasan saat dosen menulis penjelasan materi (Ario and Isharyadi, 2020).

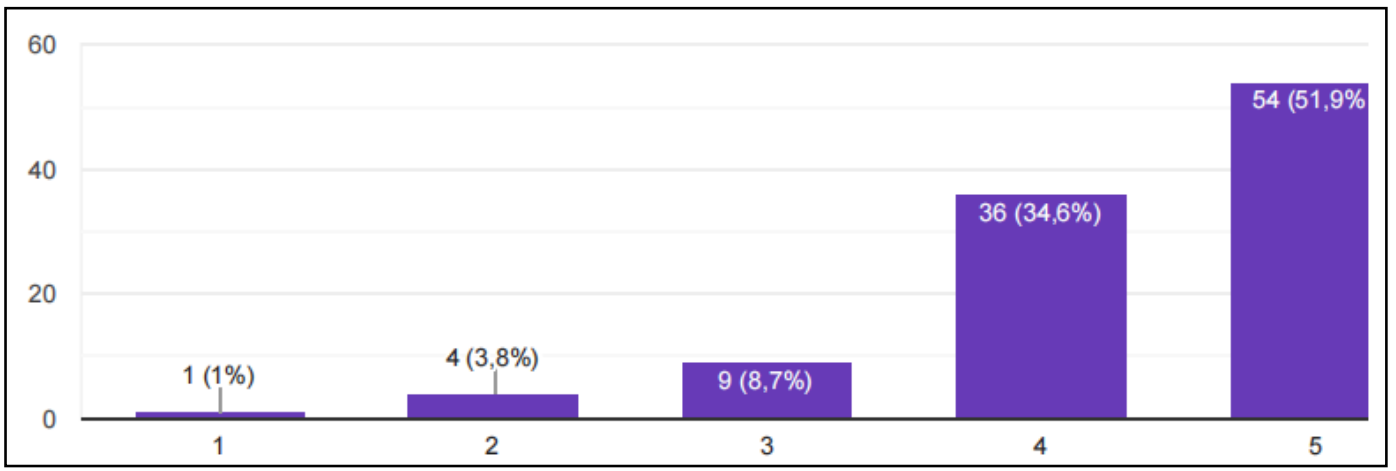

Gambar 8. Respon untuk Pernyataan 9

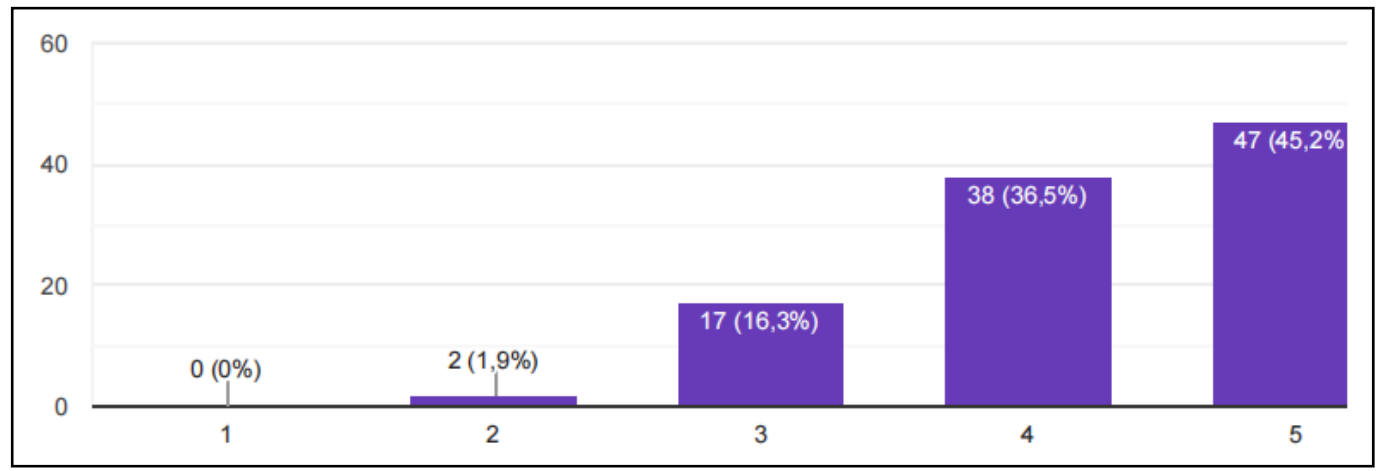

Gambar 9. Respon untuk Pernyataan 10

Pernyataan 7 berbunyi "Teknik penggunaan stylus pen akan semakin berdampak positif terhadap pemahaman jika dikolaborasikan dengan perekaman selama pembelajaran daring berlangsung". Tujuan pernyataan ini adalah untuk mengetahui respon mahasiswa terhadap kolaborasi antara teknik penggunaan stylus pen dengan pemanfaatan fitur record atau rekam layar selama pembelajaran online. Persentase terbesar dari responden memilih sangat setuju dengan pernyataan ini. Hal ini dapat dilihat pada gambar 10. Sedangkan hasil perhitungan indeks penilaian untuk pernyataan ini menunjukkan indeks sebesar 87,8\% (Tabel 
3). Berdasarkan bilangan ini dapat disimpulkan bahwa kolaborasi kedua teknik yaitu penggunaan stylus pen dan pemanfaatan fitur record selama perkuliahan online dapat berdampak positif. Begitu banyaknya kendala yang dialami dalam pembelajaran online di masa pandemi Covid-19 perlu inovasi dan kreatifitas dalam meminimalisirnya. Dalam pembelajaran offline sekalipun, untuk belajar mandiri melalui buku yang diberikan oleh dosen seringkali sulit untuk memahaminya. Apalagi kondisi pembelajaran online yang semakin menuntut untuk dapat belajar lebih mandiri, tanpa metode yang tepat tidak akan menghasilkan pembelajaran yang efektif. Selain kesulitan dalam memahami materi melalui buku teks, permasalahan lain yang dihadapi mahasiswa adalah sering lupa dengan materi yang telah dipelajari. Mereka biasanya paham ketika dijelaskan oleh dosen saat di kelas, tetapi setelah beberapa minggu mereka lupa dengan materi yang sudah dipelajari (Ario and Isharyadi, 2020). Oleh karena itu video pembelajaran online berbasis penggunaan stylus pen yang direkam seperti ini hendaknya dapat menjadi alternatif dalam mengatasi kendala-kendala tersebut.

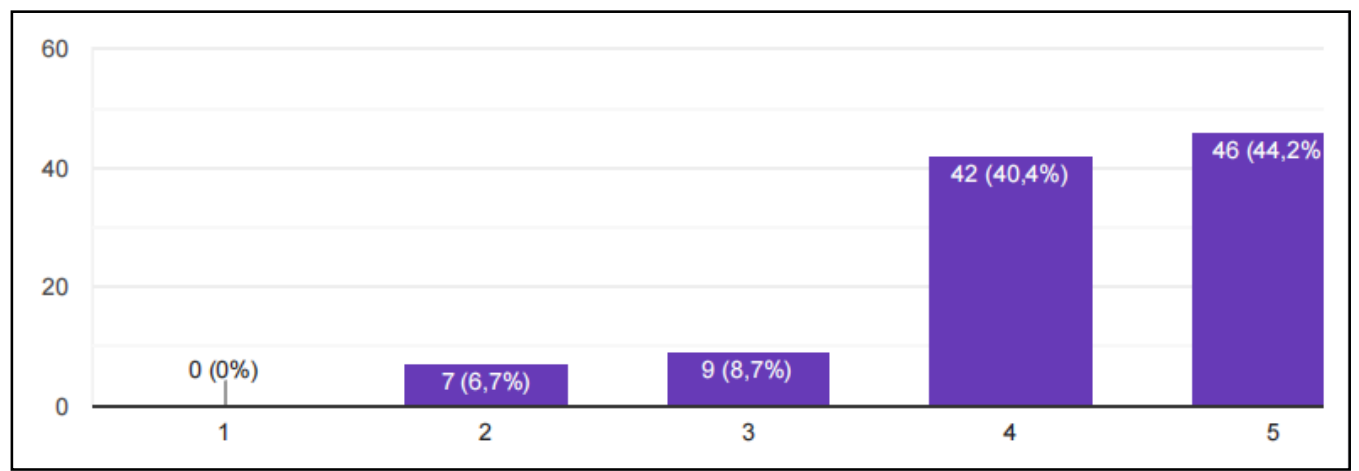

Gambar 10. Respon untuk Pernyataan 7

\section{SIMPULAN DAN SARAN}

Berdasarkan penelitian survei yang dilakukan dapat disimpulkan bahwa mahasiswa sangat setuju dengan penggunaan stylus pen dan fitur record ketika pembelajaran matematika online. Teknik penggunaan stylus pen dan fitur record ketika pembelajaran matematika online ini dapat berdampak pada pemahaman konsep matematika yang lebih baik, komunikasi matematis, suasana pembelajaran, hasil belajar, dan keefektifan pembelajaran matematika online. Disamping itu perpaduan kedua teknik juga berdampak positif terhadap pemaksimalan pemahaman konsep matematika.

Hasil penelitian ini dapat menjadi rekomendasi bagi pendidik yang mengalami kendala dalam pembelajaran matematika secara daring untuk dapat menggunakan teknik penggunaan stylus pen dan fitur record ketika pembelajaran matematika online. Selain itu juga disarankan bagi peneliti lain untuk mengembangkan video-video pembelajaran berbasis teknologi yang memaksimalkan keunggulan sofware yang saat ini sangat banyak. Tidak hanya itu, juga disarankan bagi pendidik dimanapun berada untuk menguppgrade kemampuan dalam bidang teknologi pembelajaran. 


\section{DAFTAR RUJUKAN}

Anggrawan, A. (2019) 'Analisis Deskriptif Hasil Belajar Pembelajaran Tatap Muka dan Pembelajaran online Menurut Gaya Belajar Mahasiswa', MATRIK : Jurnal Manajemen, Teknik Informatika dan Rekayasa Komputer. doi: 10.30812/matrik.v18i2.411.

Ario, M. and Isharyadi, R. (2020) 'Pengembangan Video Pembelajaran Kalkulus Diferensial Berbasis Pen Tablet', Jurnal Cendekia: Jurnal Pendidikan Matematika, 04(02), pp. 1129-1142.

Arrafi, F. (2020) Dampak Positif COVID-19 di Dunia Pendidikan, Ini 5

Faktanya! Available at: https://www.idntimes.com/life/education/kelasdaring/dampak-positif-covid-19-di-dunia-pendidikan-c1c2-1/5 (Accessed: 2 March 2021).

D. A. Muiz Lidinillah (2006) Pembelajaran Matematika di Sekolah Dasar. Available at: http://file.upi.edu/Direktori/KD-

TASIKMALAYA/DINDIN_ABDUL_MUIZ_LIDINILLAH_\%28KDTASIKMALAYA\%29-197901132005011003/132313548 - dindin abdul muiz lidinillah/Strategi Pembelajaran Matematika \%28Lokakarya Guru SD Kawalu\%29.pdf (Accessed: 3 March 2021).

Dictionary.Com (2021) Stylus | Definition of Stylus at Dictionary.com. Available at: https://www.dictionary.com/browse/stylus (Accessed: 3 March 2021).

Febrian, Astuti, P. and Antika, R. (2020) 'Pelatihan online Penggunaan Geometry Toolbox untuk Mendukung Pembelajaran Jarak Jauh pada Masa Pandemi', J-ABDIPAMAS (Jurnal Pengabdian Kepada Masyarakat)2, 4(2), pp. 9-20.

Ghifari, A. (2020) Proses Pembelajaran Edisi Pandemi Covid-19. Available at: https://www.researchgate.net/publication/345805846_Proses_Pembelajaran _Edisi_Pandemi_Covid-19 (Accessed: 3 March 2021).

Google (2021) Merekam video meeting - Pusat Pembelajaran Google Workspace. Available at: https://support.google.com/a/users/answer/9846751?hl=id (Accessed: 9 March 2021).

Isharyadi, R. and Annajmi (2019) 'Analisis Kebutuhan Bahan Ajar Video Berbasis Pen Tablet Dalam Pembelajaran ( Analysis of the Needs of Video Teaching Materials', Jurnal Matematika dan Pendidikan Matematika, 4(1), pp. 61-72.

Islamy, I. (2019) 'Penelitian Survei dalam Pembelajaran \& Pengajaran Bahasa Inggris', Pasca Sarjana Pendidikan Bahasa Inggris, (August), pp. 1-9. Available at: https://www.researchgate.net/publication/335223420_Penelitian_Survei_dal am_Pembelajaran_Pengajaran_Bahasa_Inggris. 
Kamarullah, K. (2017) 'Pendidikan Matematika Di Sekolah Kita', Al Khawarizmi: Jurnal Pendidikan dan Pembelajaran Matematika, 1(1), p. 21. doi: 10.22373/jppm.v1i1.1729.

Koswara, U. and Tita Rosita, N. (2020) 'Penerapan Video Pembelajaran Mandiri Berbantuan Software Camstudio Dan Pen Tablet Pada Perkuliahan Aljabar Linier', Symmetry: Pasundan Journal of Research in Mathematics Learning and Education, 5(volume 5), pp. 93-106. doi:

10.23969/symmetry.v5i1.2925.

Kusumaningrum, B. and Wijayanto, Z. (2020) 'Apakah Pembelajaran Matematika Secara Daring Efektif? (Studi Kasus pada Pembelajaran Selama Masa Pandemi Covid-19)', Kreano, Jurnal Matematika Kreatif-Inovatif, 11(2), pp. 139-146. doi: 10.15294/kreano.v11i2.25029.

Lubis, A. N. (2021) 'Students Mathematics Problem Solving Ability in the Era of the Effectiveness of online Mathematics Learning in Terms of Students Mathematics Problem Solving Ability in the Era of Pandemic Covid 19', (January), pp. 0-10.

Muhassanah, N., Winarni, A. and Hayati, A. (2020) 'Analisis Persepsi Mahasiswa Program Studi Matematika dalam Pembelajaran online di Masa Pandemi Covid-19', ARITHMETIC: Academic Journal of Math. doi: 10.29240/ja.v2i2.2089.

Nofrianto, A., Maryuni, N. and Amri, M. A. (2017) 'Komunikasi Matematis Siswa', Jurnal Gantang, 2(2), pp. 113-123. doi: 10.31629/jg.v2i2.199.

Pranatawijaya, V. H. et al. (2019) 'Penerapan Skala Likert dan Skala Dikotomi Pada Kuesioner online', Jurnal Sains dan Informatika, 5(2), pp. 128-137. doi: 10.34128/jsi.v5i2.185.

Purbayanti, H. S., Ponoharjo, P. and Oktaviani, D. N. (2020) 'Analisis Kebutuhan Video Pembelajaran Matematika Pada Pandemi Covid-19', JIPMat, 5(2), pp. 165-172. doi: 10.26877/jipmat.v5i2.6693.

Rahmi, R. (2020) 'Inovasi Pembelajaran Di Masa Pandemi Covid-19', $A L$ TARBIYAH: Jurnal Pendidikan (The Educational Journal), 30(2). doi: 10.24235/ath.v30i2.6852.

Silalahi, T. M. et al. (2020) 'Jurnal Mutiara Pendidikan Indonesia Analisis Kesulitan Siswa Pada Pembelajaran Matematika Di Masa Pandemi Covid19 : Studi Kasus Pada Siswa Sd Islam', 5(2). 